\title{
Benefit of Hybrid Learning in Education Using of Reusable Mask to Mothers During The Covid19 Pandemic in Pekanbaru
}

\author{
Ingrid Weddy Viva Febrya ${ }^{1^{*}}$ \\ ${ }^{1}$ STIKes Payung Negeri, Indonesia \\ “Korespondensi: ingrid anwar75@yahoo.com
}

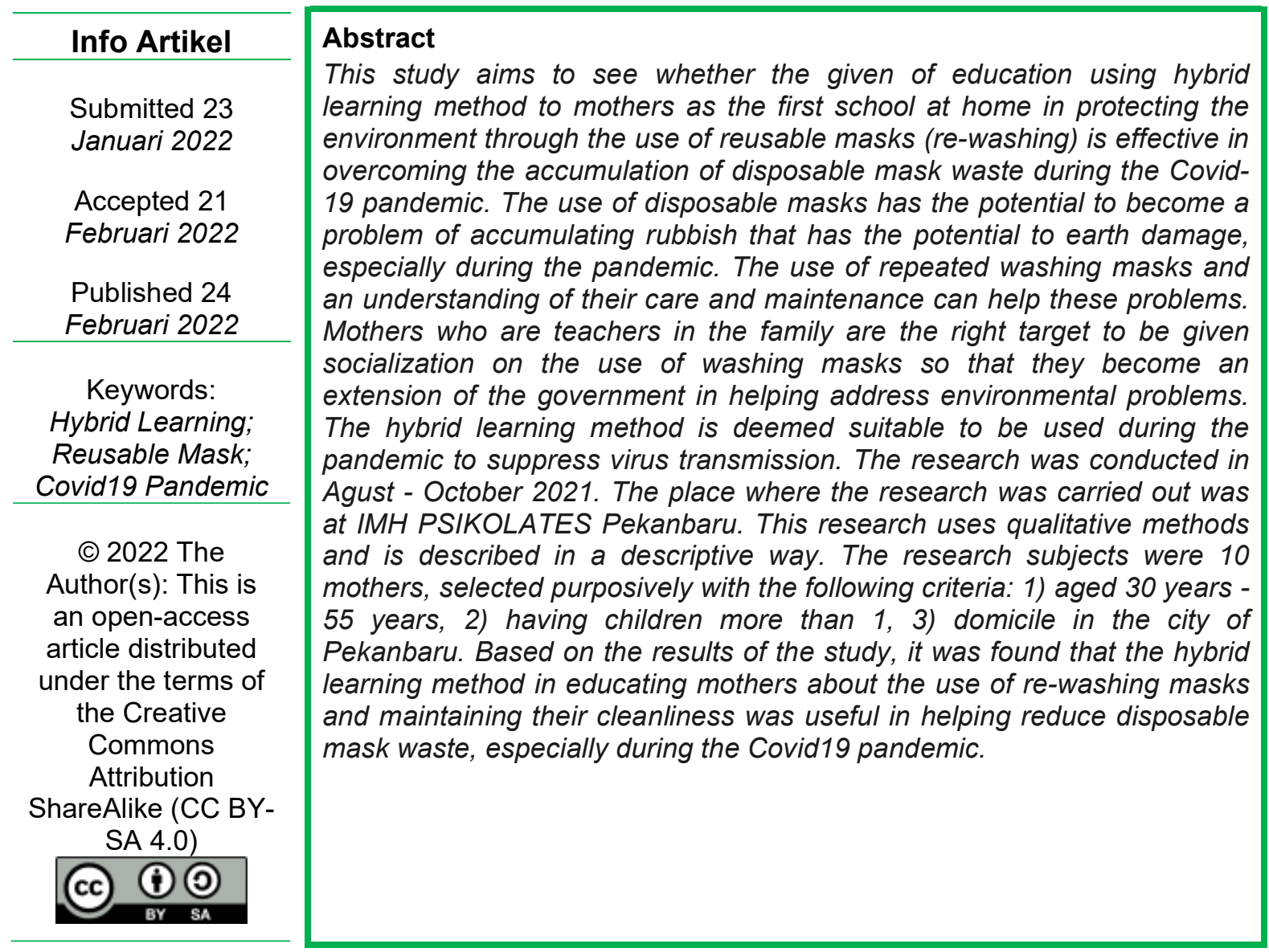

\section{Introduction}

Covid-19 pandemic which has lasted for almost 2 years has had an impact not only on changes in human health, but also on environment. Each country on this planet is intensively socializing ways to suppress the development of the virus in order to reduce the high transmission rate. The obligation of health by wearing a mask is an obligation for everyone in every activity to protect themselves and others from the threat of covid-19 transmission. An effective way in this regard is the use of a mask, where the mouth and nose are always covered so that splashes that will come out of the nose and mouth can be restrained. The use of masks is 
the best way to deal with problems during the Covid-19 pandemic. Masks are mandatory items that must be used by every people, young and old when going out of the house and doing activities. The effectiveness of the use of masks according to Atmojo et al., (2020) is that N95 masks and surgical masks have an effectiveness above $90 \%$, the recommended type of cloth mask is a 3-layer cloth mask, namely an absorbent inner layer such as cotton, a middle layer of nonwoven material such as polypropylene and an outer layer non-absorbent materials such as polyester or polyester blends.

On one side, the use of masks, both medical and non-medical masks, is a solution in responding to the pandemic, but on the other side, this creates a new problem, like the accumulation of mask waste where the use of masks has a time limit in use. According to H. A. Bangun et al. (2021), the allowed use of masks is no more than 4 hours, after a maximum of 4 hours, disposable masks must be discarded while cloth masks must be washed.

The use of disposable masks is the cause of the accumulation of mask waste and this is a threat to the environment. Based on Karmilasari et al. (2021), Changes in people's lifestyles by using masks turned out to cause new problems in the form of environmental threats from the waste of using disposable masks. Soil and sea become polluted where this threatens the life of living creatures and marine biota. This problem has found a solution by replacing disposable masks with washable masks. The danger of this mask waste is mentioned in the research of Widyaningsih et al. (2020), namely that health mask waste is B3 waste which is a hazardous and toxic material. Selvaranjan et al. (2021) also revealed that there is a huge plastic waste remained in land and marine environment in the form of mask waste, which will contribute to micro-plastic pollution.

The use of washing masks is not very popular with the public because of the lack of knowledge about the dangers of the mask waste. In order to respond to this, socialization and education are needed for the public to understand the global impact generated by single-use mask waste. The lack of health workers during the pandemic has made it difficult for the government to provide socialization to the public. Yudhastuti (2020) said that the use of cloth face mask as an alternative personal protection during the pandemic. Rizki \& Kurniawan (2020) also find that cloth face mask still can filter to a certain extend, however, it is inferior compared to surgical mask.

Mothers as family managers and teachers for children at home are the right targets in conveying information, especially health care during the Covid19 pandemic. The limitations of the implementation of face-to-face classes make learning cannot be done directly. Hybrid learning is the solution to this problem, where hybrid learning uses technology-based learning. So that information can be provided and participants can still attend classes without having to leave the house.

Based on the above background, it is necessary to conduct research on the benefits of hybrid learning in educating housewives on the use of washing masks in preserving the environment during the Covid19 pandemic. 


\section{Methodology}

This research was conducted for 3 months, sratt on Agust - October 2021. The place of research is at IMH home studio, Jalan Pengayoman no.32 Pekanbaru. The research method uses a qualitative method and is described in a descriptive way. Diah (2011) in his book entitled Qualitative Research in the field of education says that qualitative research is a type of educational research in which the researcher relies on the views of the participants, asks general and broad questions, collects data that mostly consists of words (text), describe and analyze these words into themes and carry out research that cannot be free from a sense of subjectivity and bias.

The research informants were determined as many as 9 person who were selected using purposive sampling, the sample was selected with the characteristics: 1) aged between 30 - 55 years, 2) had more than 1 children, 3) had a minimum education background of S1 and 4) lived in Pekanbaru. Research data obtained through observation, interviews and documentation. The following are informant data:

Tabel 1. Informants Data

\begin{tabular}{ccccc}
\hline No & Initial & Age & Last Education & $\begin{array}{c}\text { Understanding } \\
\text { Use of washing mask }\end{array}$ \\
\hline 1 & HH & 37 yo & S1 & Not Understand \\
\hline 2 & YO & 39 yo & S1 & Not Understand \\
\hline 3 & BH & 53 yo & D3 & Not Understand \\
\hline 4 & ESH & 48 yo & S1 & Not Understand \\
\hline 5 & RE & 40 yo & S2 & Not Understand \\
\hline 6 & ND & 35 yo & S1 & Not Understand \\
\hline 7 & AN & 29 yo & S1 & Not Understand \\
\hline 8 & IRB & 41 yo & S1 & Not Understand \\
\hline 9 & IN & 49 yo & S1 & Not Understand \\
\hline
\end{tabular}

Data analysis technique is a method in processing data into information. The goal is that research information can be understood easily. Data analysis is also needed in order to find solutions to research problems. The data analysis technique in this study used triangulation. This technique uses the results of data collection in the form of observation data, interview data and documentation data.

The observation stage was carried out before conducting the research. IMH home studio was chosen to minimize the scope of the research sample, this is based on the consideration that the members at IMH home studio only consist of mothers who already have children. The first interview stage was carried out when introducing oneself and explaining the benefits of research to informants. The questions given contained the knowledge and understanding of the informants on the use of single-use masks. After that, the informants were given education about the difference between disposable masks and washable masks and the dangers and impacts of using disposable masks for environmental conservation in 2 meetings. Hybrid learning is used in the implementation of education in adjusting to the learning system during the pandemic. After that, at the end of the meeting, a second interview was conducted again to find out whether there was a change in the perception of the informants after receiving education. The use of hybrid learning learning uses zoom meetings for 4 meetings. 
Adnan et al., (2020) in his book entitled the results of data analysis are described by means of descriptions, explaining the results of data reduction referring to the general problem formulation to be achieved. The data that has been collected is compared with one another to draw conclusions as answers to existing problems.

\section{Result}

Referring to the background, this study wants to answer two things, namely: 1) hybrid learning is useful in educating mothers during the Covid19 pandemic in understanding the difference between disposable masks and reusebable masks, 2) hybrid learning? to mother is useful in pandemic to educate in maintaining environmental safety by choosing the reuseable mask.

This research was conducted using pre-test and post-test, where the informants were given questions related to understanding the use of washing masks for environmental sustainability. The use of zoom meetings during activities is an application of using a hybrid learning method during a pandemic. The forms of activities provided in this study can be seen in the table below:

Tabel 2. Research Activity

\begin{tabular}{lcl}
\hline \multicolumn{1}{c}{ Day/Date } & Meeting & \multicolumn{1}{c}{ Activity } \\
\hline Saturday/ 21-08-21 & $\# 1$ & $\begin{array}{l}\text { - Introduction } \\
-\end{array}$ \\
\hline Tuesday/ 24-08-21 & $\# 2$ & $\begin{array}{l}\text { Materi 1 : Understanding } \\
\text { the Covid-19 pandemic }\end{array}$ \\
\hline Saturday 04-09-21 & $\# 3$ & $\begin{array}{l}\text { Materi 2 : Protecting } \\
\text { environmental health } \\
\text { through the use of re- } \\
\text { washing masks }\end{array}$ \\
& & $\begin{array}{l}\text { Materi 3 : Empowering } \\
\text { mothers in maintaining } \\
\text { family and environmental } \\
\text { health }\end{array}$ \\
\hline Saturday/ 18-09-21 & $\# 4$ & - Post-Test \\
& & - Evaluation \\
Saturday/ 02-10-21 & $\# 5$ & Closing of activities \\
\hline
\end{tabular}

First meeting, after introducing ourselves and conveying the research objectives, the informants were given by 5 questions that represented the informant's knowledge of the use of washing masks and their impact on the environment. The results of the pre-test are summarized in the table below:

Tabel 3. Pre-Test result

\begin{tabular}{|c|c|c|c|c|c|c|c|c|c|c|}
\hline No & $\begin{array}{l}\text { Questio } \\
\text { n Item }\end{array}$ & $\mathrm{HH}$ & YO & $\mathrm{BH}$ & ESH & RE & ND & AN & IRB & IN \\
\hline 1 & $\begin{array}{l}\text { do you } \\
\text { choose a } \\
\text { disposab } \\
\text { le mask } \\
\text { or a } \\
\text { reusable } \\
\text { mask? }\end{array}$ & $\begin{array}{l}\text { Disps } \\
\text { able } \\
\text { mask }\end{array}$ & $\begin{array}{l}\text { Disp } \\
\text { osab } \\
\text { le } \\
\text { mas } \\
\text { k }\end{array}$ & $\begin{array}{l}\text { Disp } \\
\text { o } \\
\text { sabl } \\
\text { e } \\
\text { mas } \\
\mathrm{k}\end{array}$ & $\begin{array}{l}\text { Dispo } \\
\text { sable } \\
\text { mask }\end{array}$ & $\begin{array}{l}\text { Disp } \\
\text { o } \\
\text { sabl } \\
\mathrm{e} \\
\text { mas } \\
\mathrm{k}\end{array}$ & $\begin{array}{l}\text { Disp } \\
\text { o } \\
\text { sabl } \\
\text { e } \\
\text { mas } \\
\mathrm{k}\end{array}$ & $\begin{array}{l}\text { Disp } \\
\text { o } \\
\text { sabl } \\
\text { e } \\
\text { mas } \\
\mathrm{k}\end{array}$ & $\begin{array}{l}\text { Reu } \\
\text { seab } \\
\text { le }\end{array}$ & $\begin{array}{l}\text { Dispo } \\
\text { sable } \\
\text { mask }\end{array}$ \\
\hline
\end{tabular}




\begin{tabular}{|c|c|c|c|c|c|c|c|c|c|c|}
\hline 2 & $\begin{array}{l}\text { do you } \\
\text { know the } \\
\text { bad } \\
\text { impact of } \\
\text { disposab } \\
\text { le masks } \\
\text { on } \\
\text { environm } \\
\text { ent? }\end{array}$ & No & No & No & Yes & Yes & No & No & Yes & Yes \\
\hline 3 & $\begin{array}{l}\text { you } \\
\text { choose } \\
\text { to use a } \\
\text { disposab } \\
\text { le mask } \\
\text { or a } \\
\text { reusable } \\
\text { mask for } \\
\text { your } \\
\text { partner } \\
\text { and } \\
\text { children, } \\
\text { what is } \\
\text { the } \\
\text { reason? }\end{array}$ & $\begin{array}{l}\text { Dispo } \\
\text { Sable } \\
\text { mask } \\
\text { is } \\
\text { Easy } \\
\text { To } \\
\text { use }\end{array}$ & $\begin{array}{l}\text { Disp } \\
\mathrm{o} \\
\text { Sabl } \\
\mathrm{e} \\
\mathrm{mas} \\
\mathrm{k} \text { is } \\
\text { Sim } \\
\text { ple }\end{array}$ & $\begin{array}{l}\text { Disp } \\
\mathrm{o} \\
\text { Sabl } \\
\mathrm{e} \\
\text { mas } \\
\mathrm{k} \text { is } \\
\text { Easy }\end{array}$ & $\begin{array}{l}\text { Dispo } \\
\text { Sable } \\
\text { mask } \\
\text { is } \\
\text { Easy }\end{array}$ & $\begin{array}{l}\text { Disp } \\
\text { o } \\
\text { Sabl } \\
\mathrm{e} \\
\text { mas } \\
\mathrm{k} \text { is } \\
\text { Easy } \\
\text { To } \\
\text { use }\end{array}$ & $\begin{array}{l}\text { Disp } \\
\mathrm{o} \\
\text { Sabl } \\
\mathrm{e} \\
\text { mas } \\
\mathrm{k} \text { is } \\
\text { Easy }\end{array}$ & $\begin{array}{l}\text { No } \\
\text { reas } \\
\text { on }\end{array}$ & $\begin{array}{l}\text { Reu } \\
\text { se } \\
\text { able } \\
\text { Mas } \\
\mathrm{k} \\
\text { Is } \\
\text { safe } \\
\text { for } \\
\text { mon } \\
\text { ey }\end{array}$ & $\begin{array}{l}\text { Dispo } \\
\text { Sable } \\
\text { mask } \\
\text { is } \\
\text { Easy } \\
\text { To } \\
\text { use }\end{array}$ \\
\hline 4 & $\begin{array}{l}\text { Do you } \\
\text { want to } \\
\text { contribut } \\
\text { e in } \\
\text { preservin } \\
\text { g } \\
\text { environm } \\
\text { ental? In } \\
\text { what } \\
\text { way? }\end{array}$ & $\begin{array}{l}\text { Yes. } \\
\text { l'm } \\
\text { not } \\
\text { Even } \\
\text { know }\end{array}$ & $\begin{array}{l}\text { Yes. } \\
\text { I'm } \\
\text { Not } \\
\text { sure }\end{array}$ & $\begin{array}{l}\text { Yes. } \\
\mathrm{Mm} \\
\mathrm{m} \\
\ldots \ldots \ldots \\
. .\end{array}$ & $\begin{array}{l}\text { Yes. } \\
\text { I was } \\
\text { Use } \\
\text { Organ } \\
\text { ic } \\
\text { things }\end{array}$ & $\begin{array}{l}\text { Yes. } \\
\text { Con } \\
\text { fuse }\end{array}$ & $\begin{array}{l}\text { Yes. } \\
\text { Say } \\
\text { no } \\
\text { To } \\
\text { plast } \\
\text { ics }\end{array}$ & $\begin{array}{l}\text { Yes. } \\
\text { I dn't } \\
\text { Kno } \\
\text { w } \\
\text { yet }\end{array}$ & $\begin{array}{l}\text { Yes. } \\
\text { Alwa } \\
\text { ys } \\
\text { use } \\
\text { Gree } \\
\text { n } \\
\text { prod } \\
\text { uct }\end{array}$ & $\begin{array}{l}\text { Yes. } \\
\text { I dn't } \\
\text { Know } \\
\text { yet }\end{array}$ \\
\hline 5 & $\begin{array}{l}\text { what do } \\
\text { you think } \\
\text { about } \\
\text { reuseabl } \\
\text { e mask } \\
\text { during a } \\
\text { pandemi } \\
\text { c? }\end{array}$ & $\begin{array}{l}\text { It's } \\
\text { okay }\end{array}$ & good & good & $\begin{array}{l}\text { norma } \\
\text { I }\end{array}$ & $\begin{array}{l}\text { I dn't } \\
\text { Hav } \\
\text { e } \\
\text { An } \\
\text { idea }\end{array}$ & $\begin{array}{l}\text { It's } \\
\text { okay }\end{array}$ & $\begin{array}{l}\text { nor } \\
\text { mal }\end{array}$ & $\begin{array}{l}\text { Very } \\
\text { good }\end{array}$ & $\begin{array}{l}\text { It's } \\
\text { okay }\end{array}$ \\
\hline
\end{tabular}

\section{Sumber: Tabel}

Based on the results of the Pre-test at the first meeting, the answers to the choice of masks used were disposable masks: 8 informants and 1 informant used disposable masks. 5 informants did not understand the bad impact of using disposable masks on the environment, while 5 informants did. Most of the informants chose to use disposable masks for reasons of convenience, while 1 informant had no reason and another 1 informant chose to use washable masks for thrifty reasons. 6 informants do not understand how to contribute in preserving 
nature, 1 informant has used organic goods and 1 informant has used environmentally friendly goods. 8 informants felt that the use of washing masks was okay, while 1 informant had no opinion.

The results above can be concluded that most of the informants are not aware that the use of disposable masks can be a natural disaster. Disposable mask waste will be a contributor to medical waste that can damage nature. Of the 9 informants, 1 informant already understood the benefits of using a washing mask for the family.

The second meeting held education about the Covid-19 pandemic. Mothers as family managers are given an understanding of the dangers of Covid-19 for families and society. The material was given by a public health expert, carried out using a Zoom meeting in the context of hybrid learning, for 90 minutes. The meeting closed with a question and answer session. The third meeting was still carried out in hybrid learning using a Zoom meeting, filled with material on the benefits of using disposable masks and the difference between disposable masks. Activities are filled by Health experts for 90 minutes. The meeting closed with games and questions and answers. The fourth meeting was filled with material on empowering housewives in maintaining family health and preserving the environment. At this meeting, informants were given the opportunity to share their experiences in maintaining the health of their families and the environment. Meetings are still being conducted in a hybrid learning manner using Zoom meetings for 90 minutes.

The fifth meeting was the last meeting in this research. At this time the material has been given and at this meeting on Post-test was carried out to see the results of education on the understanding of the informants. Post-test results can be seen in the table below:

Tabel 4. Post-Test Result

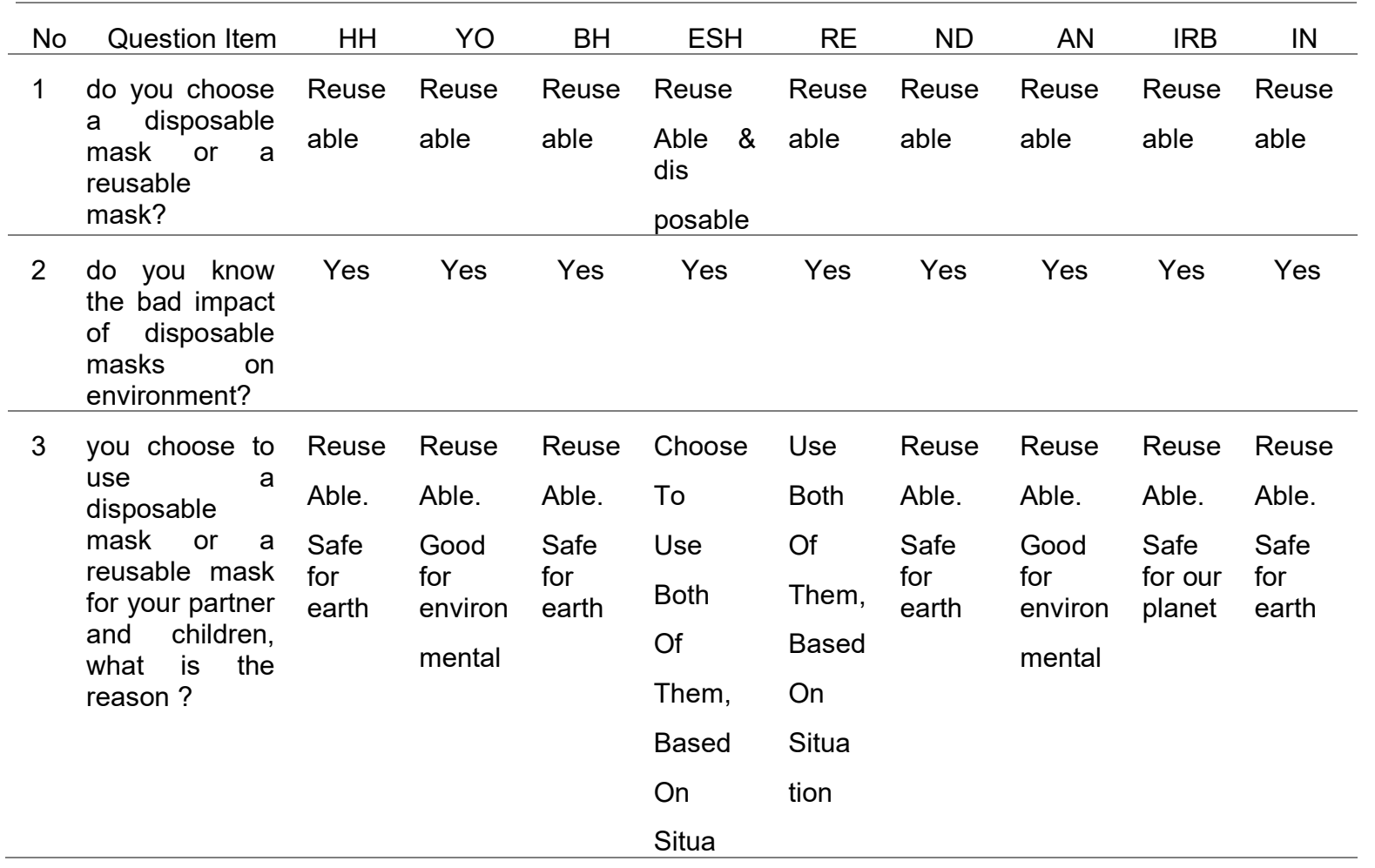




\begin{tabular}{|c|c|c|c|c|c|c|c|c|c|c|}
\hline \multirow[b]{2}{*}{4} & \multirow[b]{2}{*}{$\begin{array}{l}\text { Do you want to } \\
\text { contribute in } \\
\text { preserving } \\
\text { environmental? } \\
\text { In what way? }\end{array}$} & \multirow[b]{2}{*}{$\begin{array}{l}\text { Yes. } \\
\text { Not } \\
\text { use } \\
\text { Dispo } \\
\text { Sable } \\
\text { Mask } \\
\text { Any } \\
\text { more }\end{array}$} & \multirow[b]{2}{*}{$\begin{array}{l}\text { Yes. } \\
\text { Trying } \\
\text { Always } \\
\text { Use } \\
\text { Reuse } \\
\text { Able } \\
\text { mask }\end{array}$} & \multirow[b]{2}{*}{$\begin{array}{l}\text { Yes. } \\
\text { Throw } \\
\text { garba } \\
\text { ge in } \\
\text { its } \\
\text { place }\end{array}$} & \multicolumn{6}{|l|}{ tion } \\
\hline & & & & & $\begin{array}{l}\text { Yes. } \\
\text { trying to } \\
\text { use } \\
\text { environ } \\
\text { mentally } \\
\text { friendly } \\
\text { goods }\end{array}$ & $\begin{array}{l}\text { Yes. } \\
\text { I dn't } \\
\text { Have } \\
\text { An } \\
\text { idea }\end{array}$ & $\begin{array}{l}\text { Yes. } \\
\text { Trying } \\
\text { Always } \\
\text { Use } \\
\text { Reuse } \\
\text { Able } \\
\text { mask }\end{array}$ & $\begin{array}{l}\text { Yes. } \\
\text { Trying } \\
\text { Always } \\
\text { Use } \\
\text { Reuse } \\
\text { Able } \\
\text { mask }\end{array}$ & $\begin{array}{l}\text { Yes. } \\
\text { keep } \\
\text { the } \\
\text { green } \\
\text { life } \\
\text { style }\end{array}$ & $\begin{array}{l}\text { Yes. } \\
\text { Trying } \\
\text { Always } \\
\text { Use } \\
\text { Reuse } \\
\text { Able } \\
\text { mask }\end{array}$ \\
\hline 5 & $\begin{array}{l}\text { what do you } \\
\text { think about } \\
\text { reuseable } \\
\text { mask during a } \\
\text { pandemic? }\end{array}$ & safe & $\begin{array}{l}\text { Very } \\
\text { Good } \\
\text { choice }\end{array}$ & good & $\begin{array}{l}\text { Good } \\
\text { for } \\
\text { earth }\end{array}$ & $\begin{array}{l}\text { Safe } \\
\text { our } \\
\text { planet }\end{array}$ & $\begin{array}{l}\text { Safe } \\
\text { our } \\
\text { planet }\end{array}$ & $\begin{array}{l}\text { Safe } \\
\text { our } \\
\text { planet }\end{array}$ & $\begin{array}{l}\text { Safe } \\
\text { our } \\
\text { planet }\end{array}$ & good \\
\hline
\end{tabular}

The results of the Post-Test above can be explained that there are several answers that have changed from the informants after being educated through hybrid learning. The things that have changed are that 8 informants changed to using washable masks where previously they only used disposable masks, while 1 informant still used disposable masks and washable masks for reasons of convenience. After being educated for 3 meetings, the informants understood the importance of their contribution in keeping the earth safe from the accumulation of mask waste during the COVID-19 pandemic. Informants also have the awareness to become agents of change from the smallest community group, namely the family.

\section{Discussion}

\subsection{Hybrid Learning}

Hybrid learning comes from the word hybrid which means a combination / mixture and the word learning which means learning. The meaning of this word combination is learning that combines or mixes face-to-face learning with computer-based learning (online and offline).

The development of information and communication technology advances very rapidly, so that experts call this phenomenon a revolution. The changes that will occur are caused by the potential and capabilities of information and communication technology that allows humans to relate to each other and meet their needs. Some of the limitations that humans used to experience in dealing with one another, such as factors of distance, time, number, capacity, speed etc. can now be overcome by the development of various cutting-edge information and communication technologies.

Thorne (in Verawati \& Desprayoga, 2019) describes hybrid learning as "it represents an opportunity to integrate the innovative and technological advances offered by online learning with the interaction and participation offered in the best of traditional learning. Hybrid learning-based learning developed around 2000 in North America, the UK and Australia and is now expanding worldwide. The purpose of this learning is to provide the most effective and efficient learning experience. 
The hybrid learning model can create an effective, efficient and interesting learning process. This is confirmed by Lewis et al. (2014), the online learning experience experienced by students is the right solution to increase student participation and reduce dropout rates in the future. In addition, Andayani et al. (2020) also concluded that the hybrid learning model and problem based learning (PBS) can improve understanding of teaching materials and effectively improve learning outcomes.

The current Covid-19 pandemic has made face-to-face learning inappropriate. This situation makes the government take a policy to conduct learning with a more efficient method. Ardini, et al (2020) concluded that e-learning was considered by students to be quite effective as a learning method. There are still many obstacles faced by students when doing online learning using e-learning. However, along with the development of information technology, e-learning is expected to improve understanding of learning materials and make learning more efficient.

Based on Rahim \& Ali (2021), there are many effectiveness using social media on learning process during Covid-19 pandemic. The selection of internetbased technology learning media must be really considered, because if it is not appropriate it can have a negative impact on the benefits of learning. Various online learning platforms that are widely used to support learning include Google classroom, Zoom meeting, Whatsapp, Google meet and so on.

\subsection{Disposable Mask VS Washable Mask}

The use of disposable masks (medical masks) and reuseable masks (rewashing masks) is carried out as a health protocol during the pandemic, aiming to protect against the entry of viruses through the nose and mouth. The differences between a medical mask and a reusable mask based on Indonesian Ministry of Health:

\section{a. Ingredient}

Medical masks consist of 3 layers, namely the outer layer is waterproof, the middle layer is to filter germs and the inner layer is to absorb liquids that come out of the mouth. While the cloth mask also consists of 3 layers, namely the outer layer of a material that does not absorb liquids such as polyester or a mixture, the middle layer is made of a material that is also non-absorbent and is not woven and the inner layer is made of absorbent material such as cotton.

b. Usage

Medical masks can only be used once, after use they must be immediately discarded and cannot be reused. While cloth masks can be used many times, of course after washing after use. Therefore, re-washing masks are considered more environmentally friendly because they do not cause waste.

Putri (2020) mentioned that the combination of several variations of fabrics that are globally used for the production of cloth masks has the ability to protect the respiratory organs from the transmission of aerosol particles. Meanwhile, Hapsari \& Munawi (2021) said that the efficiency of the selection of masks is the main key in preventing the transmission of the Covid-19 virus. Droplets produced from the patient (a person infected with the Covid-19 virus) can be caught and cannot be released into the air if using a cloth mask with a porosity value in accordance with 
the standard porosity value of a surgical mask. In addition, people who use cloth masks with a porosity value of 27 which are coated with a waterproof material on the outside will also not be exposed to droplets from the outside air. A cloth mask with a porosity value of 27 does not interfere with breathing or in other words it is not too loose and not too tight when used. So that cotton-type fabrics coated with water-repellent materials with a porosity value of 27 can be chosen as materials for making masks to prevent the spread of the Covid-19 virus.

Indrawatiningsih \& Jauhari (2021) also stated that cloth mask materials can also be washed again with ordinary detergent so that it is easier for the public to clean the cloth.

take care and use it, besides that cloth masks are more environmentally friendly because they can be used repeatedly, so they will not produce waste.

Based on the opinion above, it is concluded that the use of medical masks has a weakness in its contribution to the accumulation of waste that damages the environment, while re-washing masks are considered safer for the environment.

\subsection{Empowering Mothers Through Education in Protecting Nature}

Environmental sustainability has become an important issue in recent years. Mahour (2016) says that if woman are given secure land rights, there will be a greater incentive for higher production rates. Woman will be motivated to use the best technologies, increase cultivation and make long term investments. Furthermore, Bangun (2020) say woman are very important figures to ensure sustainable development.

Empowerment is a way in which the community invited to jointly carry out an effort to fulfill a goal. According to a book by Mardikanto, (2012), Community empowerment is an effort to enable and empower society. The purpose of empowering women based on Zakiyuddin, et al (2021), is to improve health status, women's education, improve women's knowledge and skills in productive economic endeavors, increase women's participation in environmental conservation, increase the role of active women in community development and increasing national insight.

Woman empowerment is not only useful in reducing the lack of information but can also be a way for families to improve their economy and health. Kusumaningrum (2016) said that woman with low education were initially underestimated because they did not has skills that could help the family economy. However, these female employees at the SME Sago chips and tempeh in Mrisi Yogyakarta are able to become examples how women still hold on the social values of society and carry out their roles as mother and wives.

Based on Allen et al. (2020), woman face unprecedented challenges imposed by the Covid-19 pandemic. Emerging evidence suggest that women are unduly burdened by inequitable access to economic, health and social resources during the pandemic. For many women, Covid-19 has presented new urgency to challenges and illuminates unique issues long encountered. The pandemic opens up opportunities for the destruction of nature due to the waste of the use of singleuse masks. This is due to the lack of socialization and guidance to the community regarding this understanding. As an extension of the government in environmental sustainability, housewives should be involved by providing education and 
empowerment. Through this empowerment, it is hoped that mothers will not only participate in collecting their waste but are also expected to be able to participate in making their crafts. The fact that women are the center of attention is important because they play a very important role in environmental conservation.

According Siregar et al. (2020), Increased insight and skills of housewives are needed to help the community overcome their health problems. Health problems in the community often occur, among others, due to lack of knowledge in disease prevention, crowded environment, inadequate socio-economic community. The implementation of actions by increasing public knowledge and training on how to minimize the spread of infection is the concern and assistance of health workers.

Women, especially when they are mothers, have a big responsibility towards their families. In her role, women must ensure that their families are in a comfortable environment and eat good food. The role of the environment in these two things is very closely related. Therefore, women are very concerned about the environment around them. In addition, women have unique knowledge and responsibilities in sustainable use and conservation of biodiversity, and women are agents of transformational change. Pujiati \& Andalas (2018) concluded that providing education to housewives will have a huge impact on the family. Saleh (2014) concludes that the role of women in natural resource management is important because women have great potential in the success of the management and conservation of natural resources.

This shows that in protecting the environment, women can be relied on by empowering them for the smallest group, namely family, according to Qamar (2014) opinion "environmental preservation is included in the beliefe system of religious communities, both men and women".

\section{Conclusion}

Based on the results of the pre-test and post-test that have been described, it can be concluded that hybrid learning is useful in educating housewives to understand the importance of preserving nature through the use of washing masks. The Covid-19 pandemic period is not an obstacle in empowering housewives so that they can continue to contribute to the progress of the nation. Hybrid learning is the choice of learning method during limited meetings in order to prevent disease transmission.

Reuseable mask can be used as an option for people who want to be more efficient in spending and also useful in minimizing medical waste in the form of masks. Research informants who are housewives can be used as agents of change for families, so that the empowerment carried out can assist the government in responding to the rapid spike in transmission.

Suggestions for future researchers is to be able to dig deeper into how hybrid learning is easier to understand and more interesting. Education is not only limited to housewives but can empower teenagers and even social communities.

\section{References}

Adnan, G., Rukminingsih, \& Latief, M. A. (2020). Metode Penelitian Pendidikan: Penelitian Kuantitatif, Penelitian Kualitatif, Penelitian Tindakan Kelas. Erhaka Utama. 
Allen, S., Julian, Z., Coyne-Beasley, T., Erwin, P. C., \& Fletcher, F. E. (2020). Covid-19's impact on women: A stakeholder-engagement approach to increase public awareness through virtual town halls. Journal of Public Health Management and Practice, 26(6), 534-538. https://doi.org/10.1097/PHH.0000000000001249

Andayani, T., Sitompul, H., \& Situmorang, J. (2020). Pengembangan Model Pembelajaran Hybrid Learning dengan Pendekatan Problem Based Learning pada Matakuliah Pengantar Sosiologi. Jupiis: Jurnal Pendidikan IImu-IImu Sosial, 12(2), 506. https://doi.org/10.24114/jupiis.v12i2.20155

Atmojo, J. T., Iswahyuni, S., Rejo, Setyorini, C., Puspitasary, K., Ernawati, H., Rois, A., Nugroho, P., Putra, N. S., Nurrochim, Wahyudi, Setywan, N., Susanti, R. F., Suwarto, Haidar, M., Wahyudi, Iswahyudi, A., Tofan, M., Bintoro, W. A., ... Syauki, A. (2020). The Use of Masks in the Prevention and Management of COVID-19: Rationality, Effectiveness and Current Issues. Journal of Health Research, 3(2), 84-95.

Bangun, B. H. (2020). Ecofeminism and Enviromental Protection: A Legal Perspective. Jambe Law Journal, 3(1), 1-18. https://doi.org/10.22437/jlj.3.1.118

Bangun, H. A., Sinaga, L. R. V., \& Manurung, J. (2021). PKM Sosialisasi Penggunaan Masker Medis dan Kain dalam Upaya Pencegahan Covid -19 Di Uptd di Puskesmas Namohalu Esiwa Kabupaten Nias Utara. Jurnal Abdimas Mutiara, 2(1), 32-39.

Diah. (2011). Penelitian Kualitatif bidang Pendidikan. UMRI Press.

Hapsari, K. R., \& Munawi, A. (2021). Pemilihan Masker Kain dalam Mencegah Penularan Virus Covid-19. Jurnal NOE, 4(01), 2355-6684. https://ojs.unpkediri.ac.id/index.php/noe

Indrawatiningsih, N., \& Jauhari, D. M. (2021). Pembuatan Masker Kain sebagai Upaya Pencegahan Penyebaran Covid-19 di Desa Tambakrejo RT003 / RW001 Kecamatan Tongas Kabupaten Probolinggo. Jurnal Puruhita, 3(2), 66-69.

Karmilasari, V., Putri, D. S., Faedlulloh, D., \& Koswara, R. (2021). The Danger of Environmental Damage from Disposable Mask Waste During the Covid 19 Pandemic. Advances in Social Science, Education and Humanities Research, 606(licis), 272-278. https://www.atlantis-press.com/article/125965496.pdf

Kusumaningrum, D. N. (2016). Pengaruh Perspektif Pemberdayaan Perempuan dalam Kebangkitan Ekonomi Lokal: Industri Tempe Sagu di Dusun MrisiYogyakarta. Insignia Journal of International Relations, 3(02), 26. https://doi.org/10.20884/1.ins.2016.3.02.470

Lewis, S., Whiteside, A., \& Dikkers, A. G. (2014). Autonomy and Responsibility: Online Learning as a Solution for At-Risk High School Students. International Journal of E-Learning \& Distance Education, 29(2), 1-11. http://dx.doi.org/10.1016/j.learninstruc.2016.01.007

Mahour, K. (2016). Role of Women in Environment Conservation. Journal of Advanced Laboratory Research in Biology, 7(1), 17-26. https://e- 
journal.sospublication.co.in/index.php/jalrb/article/view/245\%0Ahttp://files/464 /Mahour - 2016 - Role of Women in Environment Conservation.pdf

Mardikanto. (2012). Pemberdayaan Masyarakat dalam Perspektif Kebijakan Publik. CV. Alfabeta.

Pujiati, A., \& Andalas, R. (2018). Pemberdayaan Ibu Rumah Tangga melalui Pelatihan (3M) Meningkatkan Kesejahteraan Keluarga. Jurnal PkM $\begin{array}{llll}\text { Pengabdian Kepada } & \text { Masyarakat, } & \text { 1(01), }\end{array}$ https://doi.org/10.30998/jurnalpkm.v1i01.2145

Putri, S. I. (2020). Studi Literatur: Efektivitas Penggunaan Masker Kain dalam Pencegahan Transmisi Covid-19. Jurnal Kesehatan Manarang, 6(khusus), 10.

Qamar, S. (2014). Peran Perempuan dalam Pelestarian Lingkungan Hidup Menurut Tinjauan Islam. Al-Maiyyah, 7(1), 72-85.

Rahim, M. N., \& Ali, M. B. (2021). The Effect of Using Social Media on Academic Performance of Faculty Members during Covid-19 Pandemic. Utamax: Journal of Ultimate Research and Trends in Education, 3(2), 106-114. https://doi.org/10.31849/utamax.v3i2.5934

Rizki, S. A., \& Kurniawan, A. (2020). Efficacy of cloth face mask in reducing covid19 transmis s ion: A literature review. Kesmas, 15(2), 43-48. https://doi.org/10.21109/KESMAS.V15I2.3893

Saleh, M. (2014). Partisipasi Perempuan Dalam Pengelolaan Lingkungan Hidup. Jurnal Musawa IAIN Palu, 6(2), 236-259.

Selvaranjan, K., Navaratnam, S., Rajeev, P., \& Ravintherakumaran, N. (2021). Environmental challenges induced by extensive use of face masks during COVID-19: A review and potential solutions. Environmental Challenges, 3(February), 100039. https://doi.org/10.1016/j.envc.2021.100039

Siregar, C. T., Lutfhiani, Tanjung, D., Ahmad, I., \& Ariga, R. A. (2020). Empowerment of housewife in efforts of preventing covid 19 to children in Kelurahan Sunggal. ABDIMAS TALENTA: Jurnal Pengabdian Kepada Masyarakat, 5(2), 293-301. https://doi.org/10.32734/abdimastalenta.v5i2.4888

Verawati, \& Desprayoga. (2019). Solusi Pembelajaran 4.0: Hybrid Learning. Seminar Nasional Pendidikan Program Pascasarjana Universitas PGRI Palembang, $\quad 2, \quad$ 999-1015. https://jurnal.univpgripalembang.ac.id/index.php/Prosidingpps/article/download/2739/2549

Widyaningsih, N., Cahya, D. L., \& Suprajaka. (2020). Pengelolaan Sampah Kala Covid-19. Jurnal Abdimas, 6(4), 222-225. https://doi.org/10.47007/abd.v6i4.3550

Yudhastuti, R. (2020). The use of cloth face maskduring the pandemic period inindonesian people. Kesmas, 15(2), 32-36. https://doi.org/10.21109/KESMAS.V15I2.3945 